\title{
DEVELOPING AN ECONOMETRIC MODEL FOR MEASURING THE EVOLUTION OF INFORMATION DISCLOSURE - IAS 23 BORROWING COSTS -
}

\author{
Ioana-Maria Dragu ${ }^{1}$ \\ Adriana Tiron Tudor ${ }^{2}$
}

\begin{abstract}
According to the disclosure requests of IAS 23 Borrowing Costs, companies are to include the following elements within their annual reports: accounting policies adopted by the firms, value of capitalization for borrowing costs and capitalization rate. This paper involves an empirical research, presenting the correlation that might exist at the level of compliance with IAS 23 and specific variables that characterize the activity of a company. The purpose of our investigation is to estimate and determine a statistic function that should connect disclosure index measured for IAS 23 requests and a series of elements, namely: country of origin, total assets, turnover, ROA, ROE, debt rate and solvency. The research methodology assumes disclosure index determination and SPSS analysis. The findings suggest evidence of correlation with respect to the level of compliance in information disclosure and the mentioned variables.
\end{abstract}

Key words: information, disclosure, compliance, correlation

JEL Codes: M41

\section{Introduction}

The contribution of this research for international literature relies in studying the disclosure process regarding the IAS 23 disclosure requirements in correlation to specific variables that describe the profile and operations of an entity. Having an empirical character, the paper also involves accounting practices, assuming real data for a set of 91 companies and their consolidated financial reports. The motivation for writing this article comes from the necessity of establishing an IFRS compliance level, as both IAS recognition and appliance represent essential steps for the process of accounting development.

This research concentrates on information disclosed by companies regarding their borrowing costs. According to the checklists presented by KPMG, PwC, Delloite, Ernst\&Young and to IAS 23 disclosure requests, companies are to include the following elements within their annual reports: accounting policies adopted by the firms, value of capitalization for borrowing costs and capitalization rate.

The literature review is meant to bring evidence and arguments for the selection criteria used in this study, as well as the methodology through which the research is implemented. The originality approach or the authors' contribution comes from the diversity of countries implied in the study, the areas of activity for companies, the large sample of 91 firms, and also the fact of considering market capitalization in allocating the number of entities. All these have been made in an attempt to determine IFRS compliance for disclosure of borrowing cost information, this field being very much affected by the financial crisis that created a general economic disequilibrium.

\footnotetext{
1 Babes-Bolyai University, Faculty of Economical Sciences and Administration, Cluj-Napoca, Romania, e-mail: ioanadragu@yahoo.com

2 Babes-Bolyai University, Faculty of Economical Sciences and Administration, Cluj-Napoca, Romania, e-mail: adriana.tiron@econ.ubbcluj.ro
} 


\section{Research Methodology}

As an empirical research, this article focuses on a sample of 92 companies that develop activities in 10 European countries and it uses a database of their consolidated financial reports for a period of 5 years (2005-2009).

Data gathering assumed selecting firms according to some criteria, such as industry, headquarter, or market capitalization- the last one being the main issue in allocating the number of companies for each one of the 10 countries (France, Germany, Spain, Italy, Austria, Poland, Romania, Hungary, Ukraine and Bulgaria). The methodology implies disclosure index determination, being computed as follows:

$\mathrm{DI}=\Sigma\left(\mathrm{d}_{\mathrm{i}}\right.$ effectively disclosed $) / \Sigma\left(\mathrm{d}_{\mathrm{i}}\right.$ all possible cases of disclosure $)$

The purpose of this research is to estimate an empirical model that should best describe the correlation between disclosure index of borrowing costs information and turnover, total assets, solvency, debt rate, ROE, ROA and country of origin, the econometric function being presented below:

$\mathrm{DI}_{\mathrm{t}}=\partial_{0}+\partial_{1}$ Turnover $+\partial_{2}$ Total Assets $+\partial_{3}$ Debt Ratio $+\partial_{4}$ Solvency Rate $+\partial_{5}$ Return on Assets $+\partial_{6}$ Return on Equity $+\partial_{7}$ Country of headquarter

where $t$ represents the year of study.

Another important step in research methodology assumes SPSS processing and regression analysis. This stage consists in determining the econometric models, by considering one dependent variable DI-, and other independent ones- turnover, total assets, solvency, debt rate, ROE, ROA and country of origin-. Furthermore, this study concentrates a multiple linear regression, in which linearity results from coefficients, not from variables. In addition, the model is estimated through enter method, all variables being introduced simultaneously in the regression. Practically, this method is used for theoretical or empirical models, as the one in our case, and its main characteristic is the set of predictive variables, the results showing how the exogenous variables explain the endogen ones.

\section{Literature Overview}

International accounting literature provides evidence on the fact that information disclosure is becoming more and more important for both producers and users of information. Further on, companies are interested in providing their reports with transparency, especially if they need external funds to sustain their operations and investments. On the other side, there are the shareholders, investors and other stakeholders that rely on the information disclosed by firms, and a high disclosure level would make the respective company more trustworthy.

When considering mandatory and voluntary disclosure, most seem to believe that firms that present information in low amounts might have something to hide (Fishman and Hagerty, 2007), and generally stakeholders become suspicious with them. Therefore, disclosure should be a matter of voluntary choice, and entities are to present the requested information according to their own will, not just because regulatory organisms require them.

According to Hossain (Hossain, 2008), the disclosure process can be characterized as being economically efficient, as an influencing factor for the behavior of the economic agent, a strong fundament for any decision. Studies on corporate disclosure measurement (Hossain et al. 2009) imply analysis criteria, such as: turnover, ROE, ROA, industry, activity field, country of origin, and assets. This type of research involves scoring the disclosure degree, by allocating 0 points to non disclosed and 1 for the presented elements. 
Non-compliance factors have been correlated to the disclosure trend (Street, 2001), while certain economic ratios, namely return on assets and return on equity are subject to detailed analysis in connection to borrowing costs (Bohusova and Nerudova, 2009). A study on disclosure concerning borrowing costs capitalization involving the oil and gas field reveal that borrowing costs are either expensed, or capitalized (Chung et al., 1993)

Kueppers and Sullivan identify a common point of the policies adopted by companies in practice that can lead to a 'real-time reporting' (Kueppers and Sullivan, 2010). In addition, international literature (Lang and Lundholm, 1993), mentions that improved disclosure incorporates a set of benefits for firms, as debt and equity financing rely heavily on the intensity of disclosure efforts (Barry et al., 1991).

\section{Discussion on Results}

The SPSS analysis has generated a series of Pearson's' Coefficients and Un- standardized Beta Coefficients on which our discussion of results is funded. Pearson Coefficients were used to determine and express the correlation level between the main (dependent) variable one, namely disclosure index for information on borrowing costs, and the independent ones, in the form of sales, total assets, ROA, ROE, solvency, debt rate and country. The Un-standardized Coefficients are also useful when estimating the trend of the econometric model and thus, the statistic function that results for each one of the five analyzed years. Table no. 1 shows the values obtained for Pearson Coefficients and Un-standardized Beta Coefficients, by applying the enter method during SPSS data processing.

In the first year of analysis the variables that have a strong influence on disclosure index are Sales, Total Assets, ROE and ROA. This means that those companies that register a high score for turnover or sales are also the ones that seem to publish more information. Further on, as the assets value increases, the firm is more likely to disclose a higher quantity of information. ROE and ROA are also positively correlated to disclosure index. An analysis on debt rate and solvency shows that there is negative correlation on behalf of disclosure, indicating that an increase negative correlation on behalf of disclosure, indicating that an increase in debt rate would generate a lower level of information published by firms. Regarding the country of origin, it seems that for both Romania and Italy there is low amount of disclosed information, while Hungary and Germany maintain a high level of publishing. According to our model, the econometric function for 2005 presents the following trend:

DI2005 $=0,279+5,9709 \times$ Sales $+5,3549 \times$ Total Assets $+3,9492 \times$ Debt Rate $+3,2602 \times$ Solvency + 0,110 x ROA - 1,3092 x ROE - 0,324 x Ro + 1,2692 x Bg + 0,138 x Hu - 8,9603 x Pl + $1,7782 \times \mathrm{Ur}+1,4032 \times \mathrm{Sp}-5,6652 \times \mathrm{It}+7,4092 \times \mathrm{Ge}+1,4592 \times \mathrm{Au}$

The following year shows that sales and total assets do not have a significant influence on disclosure index, while debt rate and ROE register a negative correlation regarding DI, solvency being an important influencing factor in contrast to the low correlated variable, ROA. On the whole, we noticed that an increase in solvency could generate a greater amount of published information, while a higher debt rate results in decreasing the disclosure level. If we analyze the country of origin criteria, it seems that Romania, Italy and Germany have negative correlation with respect to DI. However, Hungary and France appear to be highly positive correlated to disclosure. The regression model for year 2006 involves the following trend:

DI2006 $=0.406+3.4239 \times$ Sales $+9.2549 \times$ Total Assets $-5.766 \times$ Debt Rate +5.8132 x Solvency $-2.3752 \times \mathrm{ROA}+4.2313 \times \mathrm{ROE}-0,435 \times \mathrm{Ro}-9.7562 \times \mathrm{Bg}+0,118 \times \mathrm{Hu}-9.4892 \times \mathrm{Pl}-7.1512 \times$ $\mathrm{Ur}-5.2562 \times \mathrm{Sp}-0.143 \times \mathrm{It}-5.5502 \times \mathrm{Ge}-6.8652 \times \mathrm{Au}$ 


\section{Correlation and model determination-SPSS data processing and analysis}

Table no.1.

\begin{tabular}{|c|c|c|c|c|c|c|c|c|c|c|}
\hline \multirow{2}{*}{ Variables } & \multicolumn{5}{|c|}{ Pearson's Correlation Coefficient } & \multicolumn{5}{|c|}{ Un-standardised Beta Coefficient } \\
\hline & 2005 & 2006 & 2007 & 2008 & 2009 & 2005 & 2006 & 2007 & 2008 & 2009 \\
\hline Significance & \multicolumn{2}{|c|}{$*$, for Sig $\leq 0,10$} & $* *$, for $\mathrm{Sig} \leq 0,05$ & \multicolumn{2}{|c|}{$* * *$, for $\operatorname{Sig} \leq 0,01$} & 279 & ,406 & ,381 & $9,474 \mathrm{E}-02$ & ,518 \\
\hline Sales & 0,102 & 0,076 & 0,073 & 0,132 & 0,076 & 5,970E-09 & $3.42 \mathrm{E}-06$ & $3,099 \mathrm{E}-08$ & $3,983 \mathrm{E}-07$ & $1,183 \mathrm{E}-07$ \\
\hline Total Assets & 0,105 & 0,093 & 0,051 & 0,091 & 0,070 & $5,354 \mathrm{E}-09$ & $9.25 \mathrm{E}-06$ & $-1,750 \mathrm{E}-08$ & $-3,702 \mathrm{E}-07$ & $-8,611 \mathrm{E}-08$ \\
\hline Debt Rate & $-0,058$ & $-0,185 * *$ & $-0,214 * *$ & 0,062 & $0,159 *$ & $3,949 \mathrm{E}-02$ & $-5.77 \mathrm{E}-02$ & $-1,845 \mathrm{E}-02$ &, 235 &,- 101 \\
\hline Solvency & 0,075 & 0,187 ** & $0,211 * *$ & -0.073 & $-0,181 * *$ & $3,260 \mathrm{E}-02$ & $5.81 \mathrm{E}+01$ & $6,058 \mathrm{E}-02$ & ,331 & $-8,861 \mathrm{E}-02$ \\
\hline $\mathrm{ROA}$ & $0,224 * *$ & 0,024 & 0,115 & 0,003 & $-0,031$ &, 110 & $-2.38 \mathrm{E}-02$ & $-1,403 \mathrm{E}-02$ & $5,622 \mathrm{E}-03$ &,- 443 \\
\hline $\mathrm{ROE}$ & $0,216 * *$ & $-0,005$ & $-0,027$ & 0,009 & $-0,011$ & $-1.309 \mathrm{E}-02$ & $-4.23 \mathrm{E}+00$ & $3,767 \mathrm{E}-03$ & $-5,951 \mathrm{E}-04$ & $9,498 \mathrm{E}-02$ \\
\hline Romania (Ro) & $-0,545 * * *$ & $-0,529 * * *$ & $-0,564 * * *$ & $-0,450 * * *$ & $-0,432 * * *$ &,- 324 &,- 435 &,- 419 &,- 413 &,- 413 \\
\hline Bulgaria $(\mathrm{Bg})$ & 0,025 & 0,007 & 0,011 & 0,003 & $-0,034$ & $1,269 \mathrm{E}-02$ & $9.76 \mathrm{E}-02$ & $-8,288 \mathrm{E}-02$ & $1,609 \mathrm{E}-02$ &,- 109 \\
\hline Hungary $(\mathrm{Hu})$ & $0,255 *$ & $0,305 * *$ & $0,229 * *$ & $0,170 *$ & $0,147 *$ & , 138 &, 118 & $5,577 \mathrm{E}-02$ & $4,135 \mathrm{E}-02$ &, 11 \\
\hline Poland (Pl) & 0,056 & 0,0015 & 0,024 & 0,006 & $-0,075$ & $-8.960 \mathrm{E}-03$ & $-9.49 \mathrm{E}-02$ & $-9,031 \mathrm{E}-02$ & $-4,705 \mathrm{E}-02$ & $-8,185 \mathrm{E}-02$ \\
\hline Ukraine (Ur) & 0,031 & 0,008 & 0,013 & 0,003 & 0,130 & $1,778 \mathrm{E}-02$ & $-7.15 \mathrm{E}-02$ & $-6,698 \mathrm{E}-02$ & $-3,669 \mathrm{E}-02$ &, 134 \\
\hline Spain $(\mathrm{Sp})$ & 0,066 & 0,017 & 0,028 & 0,007 & $-0,089$ & $1,403 \mathrm{E}-02$ & $-5.26 \mathrm{E}-02$ & $-5,271 \mathrm{E}-02$ & $-2,841 \mathrm{E}-02$ & $-8,765 \mathrm{E}-02$ \\
\hline France $(\mathrm{Fr})$ & 0,042 & 0,231 ** & $0,263 *$ & 0,097 & 0,079 & & & & & \\
\hline Italy (It) & $-0,175 * *$ & 0,127 & 0,129 & $-0,114$ & $-0,080$ & $-5.665 \mathrm{E}-02$ &,- 143 &,- 137 &,- 107 & $-9,158 \mathrm{E}-02$ \\
\hline Germany (Ge) & $0,139 *$ & 0,043 & 0,036 & 0,060 & 0,201 & $7,409 \mathrm{E}-02$ & $-5.55 \mathrm{E}-02$ & $-5,867 \mathrm{E}-02$ & $-3,097 \mathrm{E}-03$ & $4,688 \mathrm{E}-02$ \\
\hline Austria $(\mathrm{Au})$ & 0,052 & 0,014 & 0,022 & 0,139 & 0,092 & $1,459 \mathrm{E}-02$ & $-6.87 \mathrm{E}-02$ & $-6,711 \mathrm{E}-02$ & $6,163 \mathrm{E}-02$ & $4,002 \mathrm{E}-02$ \\
\hline
\end{tabular}

(Source: SPSS data processing) 
The correlation coefficients obtained for year 2007 demonstrate that as solvency increases in value, the company tends to supply more information about borrowing costs. Hence, a higher debt rate involves less information disclosed in consolidated financial statements. Regarding the analyzed countries, Hungary performs with a high correlation to DI, accompanied by France. On the other side, there are the negative correlations of Italy and Romania, these countries maintaining a low amount of published information. Therefore, the representative function for 2007 can be described as follows:

DI2007 $=0,381+3,0998 \times$ Sales $-1,758 \times$ Total Assets $-1,8452 \times$ Debt Rate $+6,0582 \times$ Solvency $-1,4032$ x ROA + 3,7673 x ROE - 0,419 x Ro - 8,2882 x Bg + 5,5772 x Hu - 9.0132 x Pl - 6,6982 x Ur $-5,2712$ x Sp $-0,137$ x It $-5,8672$ x Ge $-6,7112$ x Au

In 2008, there is evidence for the fact that the higher the turnover, the most likely for the firm to become more careful with the information they disclose, and to publish more as to fulfil the needs of the users of accounting information. The ROE and ROA do not represent significant factors for DI during this specific period. The same for total assets and debt rate, which show low correlation levels. When considering the countries included in this study, coefficients still have a negative sign for Romania, leading to the same conclusions as in previous cases. The econometric function is defined by a new regression model:

DI2008 $=9,4742+3,9837 \times$ Sales $-3,7027 \times$ Total Assets $+0,235 \times$ Debt Rate $+0,331 \times$ Solvency $+5,6223 \times \mathrm{ROA}-5,9514 \times \mathrm{ROE}-0,413 \times \mathrm{Ro}+$ Debt Rate + 0,331 x Solvency + 5,6223 x ROA 5,9514 x ROE $-0,413 \times \mathrm{Ro}+1,6092 \times \mathrm{Bg}+4,1352 \times \mathrm{Hu}-4,7052 \times \mathrm{Pl}-3,6692 \times \mathrm{Ur}-2,8412 \times$ $\mathrm{Sp}-0,107 \times \mathrm{It}-3,0973 \times \mathrm{Ge}+6,1632 \times \mathrm{Au}$

Regarding the last period of analysis, in 2009 we notice that an increase in debt rate would generate increased disclosure, while turnover and total assets do not represent a significant influence. Higher values for solvency, ROE and ROA would mean lower quantities of disclosed information. Ukraine, Hungary and Germany have significant and positive correlations with DI. The explanation is that companies with headquarters in these three countries maintain a high level of information disclosure regarding IAS 23. The model can be described below:

DI2009 $=0,518+1,1837 \times$ Sales $-8,6118 \times$ Total Assets $-0,101 \times$ Debt Rate $-8,8612 \times$ Solvency $-0,443 \times \mathrm{ROA}+9,4982 \times \mathrm{ROE}-0,413 \times \mathrm{Ro}-0,019 \times \mathrm{Bg}+0,112 \times \mathrm{Hu}-8,1852 \times \mathrm{Pl}+0,134 \times$ $\mathrm{Ur}-8,7652 \times \mathrm{Sp}-9,1582 \times \mathrm{It}+4,6882 \times \mathrm{Ge}+4,0022 \times \mathrm{Au}$

\section{Conclusions}

This paper presents the correlation at the level of compliance with IAS 23 and specific variables that characterize the activity of a company. The purpose of this research is to estimate and determine a statistic function that should connect disclosure index measured for IAS 23 requests and a series of elements, namely: country of origin, total assets, turnover, ROA, ROE, debt rate and solvency.

As research perspective, we are aiming to test the model on a larger sample, and first conducting a study on Romanian companies, to expand afterwards the study at European level. Another research discussion could focus on the criteria of economic development of the selected countries, and grouping them into well-developed and under-developed. We also intend to perform an analysis on financial reporting trends in years 2010 and to perform an analysis on financial reporting trends in years 2010 and 2011.

Finally, we have to add that the study has some limitations, in the form of the finite number of selected companies and countries. If the database assumed more than 10 states or 92 firms, it 
would have been possible for the correlation to be different. In other words, the model should be continuously tested in order to verify its validity and relevance at the level of the whole population. Also, there are several criteria that should be met by an econometric model so as to be declared as valid. In what concerns this research, the validity is representative for the chosen sample, of the 92 companies, and their corresponding countries. Furthermore, this paper concentrates on the correlation between the dependent variable- information disclosure for borrowing costs -, and the independent ones - country of origin, turnover, total assets, debt rate, solvency, ROA and ROE -, or the connection between elements, not aiming to demonstrate that the model is valid for the entire population, which could be a challenge for future manuscripts.

\section{References}

1. Bohusova H., Nerudova. D., 2009. IFRS and US GAAP Convergence in the area of Borrowing Costs, International Journal of Business Research, 9, 35-39.

2. Barry M., Benson E.D., Raman K.K., 1991. The Effect of Voluntary GAAP Compliance and Financial Disclosure on Governmental Borrowing Costs, Journal of Accounting, Auditing, and Finance, 6, 303-319.

3. Booth J.R., Boothm L.C., 2006. Loan Collateral Decisions and Corporate Borrowing Costs, Journal of Money, Credit and Banking, 38, 70-72.

4. Chung K.H., Ghicas D., Pastena V., 1993. Lenders' Use of Accounting Information in the Oil and Gas Industry, The Accounting Review, 68, 885-895.

5. Hossain M.A., Akhtaruddin M., Yao L., 2009. Corporate Governance and Voluntary Disclosure in Corporate Annual Reports of Malaysian Listed Firms, Journal of Applied Management Accounting Research, 7, 1-20.

6. Hossain M., 2008. The Extent of Disclosure in Annual Reports of Banking Companies: The Case of India, European Journal of Scientific Research, 4, 660-681.

7. Kueppers R.J., Sullivan K.B., 2010. How and why an independent audit matters, International Journal of disclosure and governance. 7, 286-293.

8. Lang M., Lundholm R., 1993, Cross-sectional determinants of analyst ratings of corporate disclosures, Journal of Accounting Research. 31, 246-271.

9. Lee M.H., 2010. Evaluation of Annual Reports on Human Resource Disclosure using content analysis, Unitar E-Journal, 6.

10. Street D., 2001. Observance of International Accounting Standards: Factors explaining noncompliance, ACCA Research Report, 74, 1-127. 